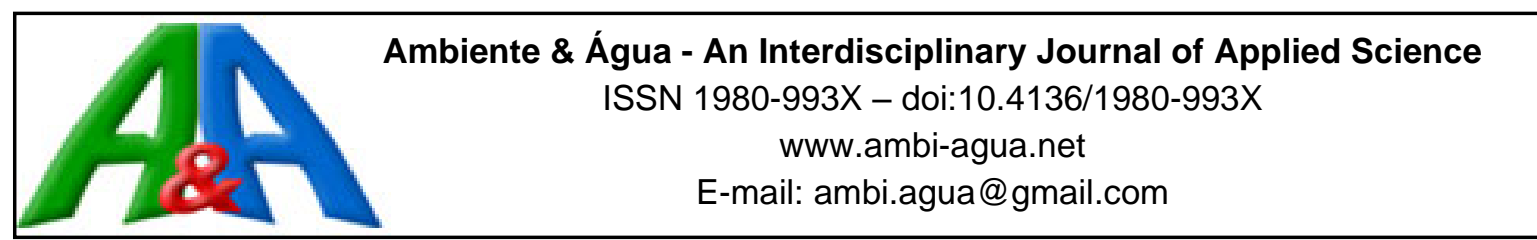

\title{
Nutrient removal efficiency using microalgae in different photoperiod cycles, combined with constructed wetland in a wastewater treatment plant
}

\author{
ARTICLES doi:10.4136/ambi-agua.2692
}

Received: 05 Jan. 2021; Accepted: 17 Aug. 2021

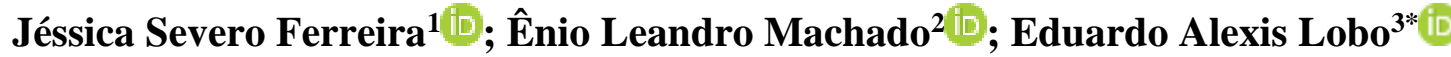

${ }^{1}$ Programa de Pós-graduação em Tecnologia Ambiental. Universidade de Santa Cruz do Sul (UNISC), Avenida Independência, n 2293, CEP: 96816-501, Santa Cruz do Sul, RS, Brazil. E-mail: jessica_severo@msn.com ${ }^{2}$ Departamento de Química e Física. Universidade de Santa Cruz do Sul (UNISC), Avenida Independência, n² 2293, CEP: 96816-501, Santa Cruz do Sul, RS, Brazil. E-mail: enio@unisc.br

${ }^{3}$ Departamento de Ciências da Vida. Universidade de Santa Cruz do Sul (UNISC), Avenida Independência, $n^{\circ}$ 2293, CEP: 96816-501, Santa Cruz do Sul, RS, Brazil.

*Corresponding author. E-mail: lobo@unisc.br
\end{abstract}

\begin{abstract}
This research evaluates the removal of nutrients by microalgae in different photoperiod cycles, combined with constructed wetland in the wastewater treatment plant of the University of Santa Cruz do Sul, RS, Brazil. The treatment used took place between July and December 2018 and consisted of the following steps: preliminary treatment, secondary treatment with an anaerobic reactor, microalgae tank (MT), sand filter and constructed wetland, using the macrophyte Chrysopogon zizanioides. In the microalgae tank, three light cycles were considered: $12 \mathrm{~h} / 12 \mathrm{~h}, 24 \mathrm{~h}$ and $18 \mathrm{~h} / 06 \mathrm{~h}$, whose lighting was powered by a white LED lamp of 9 Watts and 6000 Kelvin, regulated by a light controller. The results indicated that there were no significant differences ( $>>0.05$ ) between the values of soluble phosphorus, ammoniacal nitrogen, COD and BOD for MT comparing the three photoperiod cycles $(12 \mathrm{~h} / 12 \mathrm{~h}, 24 \mathrm{~h}$ and $18 \mathrm{~h} / 06 \mathrm{~h})$. However, the system setup removed $100 \%$ of total coliforms, E. coli and TSS in the three light cycles. Regarding the removal of nutrients and organic matter, the light cycle with the best performance was the 24-hour cycle, considering a removal of $67.6 \%$ for soluble phosphorus, $94.0 \%$ for ammoniacal nitrogen, $63.7 \%$ for COD and 42, 7\% for BOD, at the end of the treatment process. These results demonstrate that the use of microalgae in combination with constructed wetland has greater efficiency in the removal of nutrients, mainly phosphorus and nitrogen, in addition to reducing physical-chemical parameters and eliminating effluent toxicity.
\end{abstract}

Keywords: light cycles, microalgae tank, wastewater treatment plant.

\section{Eficiência de remoção de nutrientes utilizando microalgas em diferentes ciclos de fotoperíodos para uso combinado com wetland construído no tratamento de águas residuais}

\section{RESUMO}

Esta pesquisa teve como objetivo avaliar a remoção de nutrientes por microalgas em 
diferentes ciclos de fotoperíodo, combinado com wetland construído na Estação de Tratamento de Efluentes da Universidade de Santa Cruz do Sul, RS, Brasil. O tratamento empregado ocorreu entre julho e dezembro de 2018 e consistiu nas seguintes etapas: tratamento preliminar, tratamento secundário com reator anaeróbio, tanque de microalgas (TM), filtro de areia e wetland construído, utilizado a macrófita Chrysopogon zizanioides. No tanque de microalgas, foram considerados três ciclos de luz: $12 \mathrm{~h} / 12 \mathrm{~h}, 24 \mathrm{~h}$ e $18 \mathrm{~h} / 06 \mathrm{~h}$, cuja iluminação era alimentada por uma lâmpada LED branca de 9 Watts e 6000 Kelvin, regulada por um controlador de luz. Os resultados indicaram que não houve diferenças significativas $(p>0,05)$ entre os valores de fósforo solúvel, nitrogênio amoniacal, DQO e DBO para TM comparando os três ciclos de fotoperíodo (12h/12h, 24h e 18h /06h). No entanto, a configuração do sistema removeu 100\% de coliformes totais, E. coli e TSS nos três ciclos de luz. Em relação à remoção de nutrientes e matéria orgânica, o ciclo de luz com melhor desempenho foi o de 24 horas, considerando a remoção de 67,6\% para fósforo solúvel, 94,0\% para nitrogênio amoniacal, 63,7\% para DQO e $42,7 \%$ para DBO, no final do processo de tratamento. Esses resultados demonstram que o uso de microalgas em combinação com wetland construído tem maior eficiência na remoção de nutrientes, principalmente fósforo e nitrogênio, além de reduzir parâmetros físico-químicos e eliminar a toxicidade do efluente.

Palavras-chave: ciclos de luz, estação de tratamento de efluentes, tanque de microalgas.

\section{INTRODUCTION}

Human activities and industrial production are leading to an increase in the release of contaminants into water resources, which is currently one of the biggest environmental problems in the world (Arihilam and Arihilam, 2019). According to Lobo et al. (2016), the eutrophication process is one of the main causes of the degradation of water resources, due to the high discharge of nutrients from sewage into water bodies, mainly nitrogen and phosphorus. Eutrophication is a worldwide problem that induces a strong deterioration of rivers, dams, lakes and coastal waters, causing numerous direct and indirect effects on aquatic biodiversity. Furthermore, eutrophication compromises the multiple uses of water resources, including water for human consumption, causing substantial damage to the local and regional economy. Currently, eutrophication is a threat to public health and the general operating conditions of aquatic systems, constituting an important economic factor that can prevent or delay sustainable development (Tundisi and Matsumura-Tundisi, 2008). Thus, to protect water resources and public health, there is a growing demand for efficient treatment systems that can mitigate or even eradicate the impacts generated by inadequate sewage management (Metcalf and Eddy, 2016).

There are several methods used to treat wastewater, including biological treatment, which uses organisms to remove pollutants from wastewater (Yi et al., 2020). An example is the use of Constructed Wetlands (CW's), which are artificial filters that simulate the ecological processes found in natural ecosystems. They are composed of a support medium, such as sand and gravel, in addition to microorganisms and macrophytes that clean wastewater through physical, chemical and biological processes (Liang et al., 2017). Macrophytes are essential components of $\mathrm{CW}$ to remove contaminants such as phosphorus, nitrogen and heavy metals. Furthermore, macrophytes stems, leaves and roots provide fixation sites for microorganisms, being highly essential for the removal of contaminants (Wang et al., 2018). According to Rehman et al. (2017), several studies report the effectiveness of using macrophytes to improve the physical-chemical characteristics of effluents, being efficient in removing suspended solids, biochemical oxygen demand, nutrients, heavy metals and reducing pathogenic microorganisms. Along with constructed wetlands, microalgae can be used to improve wastewater 
treatment, as these microorganisms use sewage nutrients for their growth, such as ammonia, nitrate, phosphate and urea (Salama et al., 2017). According to Vacca-Jimeno et al. (2017), microalgae can be used to treat various types of effluents (e. g., domestic, agricultural, industrial), considering their tolerance to high concentrations of nutrients (nitrogen and phosphorus) and organic matter (Lobo et al., 2016). Among the advantages of using microalgae, Pacheco et al. (2015) cite the low economic cost, since its development depends only on water, light and $\mathrm{CO}_{2}$, being able to survive and reproduce in different environments.

One of the few studies that uses microalgae and CW's in combination is that by Celente et al. (2019), where microalgae were exposed to natural light conditions, with a significant reduction in parameters such as conductivity (49\%), total dissolved solids (48\%), turbidity (98\%), apparent color (82\%), ammoniacal nitrogen (99\%), total nitrogen (70\%), soluble phosphorus (44\%), total organic carbon (69\%), inorganic carbon (86\%), total carbon $(83 \%)$ and chemical oxygen demand (72\%). In addition, this system completely eliminated acute toxicity and genotoxicity, showing that the proposed system combining the two techniques is suitable for the treatment of effluents (Celente et al., 2020).

In this context, this research evaluates the removal of nutrients by microalgae in different photoperiod cycles combined with CW's, in the effluent treatment plant of the University of Santa Cruz do Sul, RS, Brazil.

\section{MATERIALS AND METHODS}

\subsection{Wastewater and combined treatment system}

An experimental unit was built at the wastewater treatment plant of the University of Santa Cruz do Sul (UNISC), Santa Cruz do Sul City, State of Rio Grande do Sul, Brazil, at the geographic coordinates $29^{\circ} 43^{\prime} 59^{\prime \prime} \mathrm{S}$ and $52^{\circ} 24^{\prime} 52^{\prime \prime} \mathrm{O}$ (WGS84). The study period took place from March to December 2018.

A preliminary treatment of the raw effluent (Raw) from the University's toilets basically includes sand washing, drainage and an equalized tank, followed by secondary treatment by an anaerobic reactor (AR), corresponding to a Bakof Tec Multi Biodigester of 1,450 liters. After the secondary treatment, the effluent was directed to the developed system, which had a series configuration of three boxes of two hundred liters each, produced with high-density polyethylene material (HDPE) and rectangular in shape (92 cm long; $55 \mathrm{~cm}$ wide; $58.5 \mathrm{~cm} \mathrm{high).}$ To facilitate the transportation of the effluent by gravity, the three boxes were installed in a step-like structure, with the first box (MT) of the system located $1.4 \mathrm{~m}$ above the ground, the second (SB) at $75 \mathrm{~cm}$ and the third $(\mathrm{CW})$ at $10 \mathrm{~cm}$ from the ground, with a horizontal distance of approximately $5 \mathrm{~cm}$ between each box. Figure 1 shows the proposed effluent treatment system.

\subsection{System Configuration}

The first box of the system corresponds to the microalgae tank (MT) that receives the effluent from the anaerobic reactor (AR) by means of a hydraulic pump, with an engine power of $1 / 2 \mathrm{hp}$ and maximum flow of $1.8 \mathrm{~m}^{3} \mathrm{~h}^{-1}$. In the MT, an acrylic support with a double roughness layer was installed to facilitate microalgae adhesion on the biofilm. There was no microalgae inoculation, so the biofilm formed spontaneously. In addition, it had a $45^{\circ}$ inclination and the acrylic layers were approximately $1.5 \mathrm{~cm}$ apart, with a surface area of $0.54 \mathrm{~m}^{2}$. In this box, the effluent was recirculated by an 8 Watt submersible pump with a flow rate of $520 \mathrm{~L} \mathrm{~h}^{-1}$. The system also had automatic lighting by a 9 Watt 6000K White Light tubular LED lamp, with 60 $\mathrm{cm}$ of length, regulated by a light controller. To reduce the influence of the external environment by sunlight, this box was covered with a vinyl tarpaulin and aluminum foil.

The sand biofilter tank (SB) consisted of a $15-\mathrm{cm}$ basaltic gravel layer $(64-100 \mathrm{~mm})$ at the bottom, following by a $40-\mathrm{cm}$ basaltic crushed stone $(19-25 \mathrm{~mm})$ and $15-\mathrm{cm}$ basaltic crushed 
stone $(25-50 \mathrm{~mm})$ filtering layer, and finally a thin sand layer. The constructed wetland $(\mathrm{CW})$ consisted of a 15-cm basaltic gravel (64-100 mm) layer at the bottom for drainage and a 40-cm basaltic crushed stone (19-25 mm) filtering layer planted with Chrysopogon zizanioides (L.) Roberty; commonly known as vetiver is a perennial grass of the Poaceae family (BFG, 2015), using 16 shoots planted per square meter. The effluent had a hydraulic retention time (HDT) of 7 days in each system configuration.

To assess the efficiency of microalgae growth in different cycles of photoperiod, three different light cycles were used: $12 \mathrm{~h} / 12 \mathrm{~h}, 24 \mathrm{~h}$ and 18h/06h (light/dark), each lasting seven weeks. The 24-hour photoperiod was determined for comparison with other similar studies on nutrient removal using microalgae by Sukačová et al. (2015).

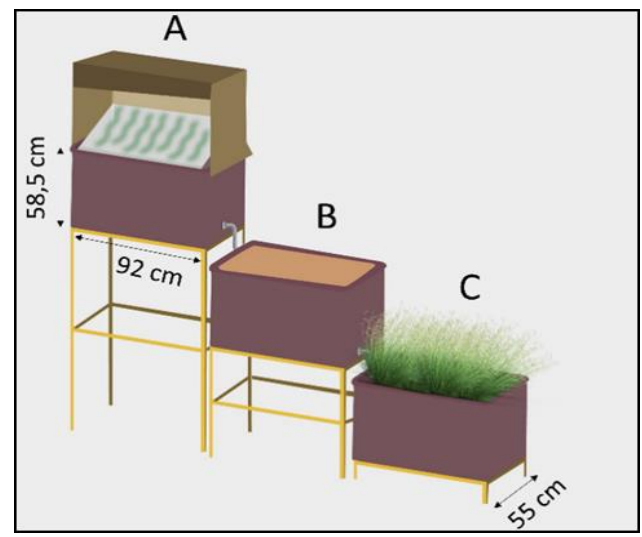

Figure 1. Proposed effluent treatment system. The anaerobic reactor effluent is directed to the first box composed of the microalgae tank (A), passes through the sand biofilter (B) and finally through the constructed wetland $(\mathrm{C})$.

\subsection{Effluent Characterization}

All samples characterized according to the following parameters: chemical oxygen demand (COD), turbidity, $\mathrm{pH}$, conductivity, total suspended solids (TSS), total dissolved solids (TDS), apparent color, soluble phosphorus, total nitrogen (TN), and ammoniacal nitrogen $\left(\mathrm{NH}_{3}\right)$ according to APHA et al. (2012). Total carbon (TC), total organic carbon (TOC), and inorganic carbon (IC) according to Fonseca et al. (2006).

\subsection{Acute Ecotoxicity}

The assessment of acute ecotoxicity was performed following the Brazilian standard NBR 12713 (ABNT, 2016). All analyses were duplicated and consisted of 10 individuals of Daphnia magna Straus, a small planktonic crustacean (adult length 1.5-5.0 $\mathrm{mm}$ ) that belongs to the subclass Phyllopoda (Gruiz and Molnár, 2015), popularly known as water flea, exposed to a 25 $\mathrm{mL}$ of samples belonging to Raw and CW. After 24 and 48 hours of exposure, we quantified the mobile and immobile individuals in each sample, and the concentration capable of causing immobility in $50 \%$ of the exposed individuals, EC $_{50}(48 \mathrm{~h})$, calculated by the Trimmed Spearman-Karber software (Hamilton et al., 1977). Results were classified according to the scale of relative toxicity proposed by Lobo et al. (2006), and recently certified by Celente et al. (2020).

\subsection{Pathogenic microorganisms}

The analysis of total coliforms and Escherichia coli was performed on samples of raw and treated effluent, according to AOAC (2000) on Petrifilm TM 3M® plates. 


\subsection{Data analysis}

Descriptive statistics was used for data analysis (mean \pm standard deviation; Coefficient of Variation, CV). Significant differences were established by the non-parametric Mann-Whitney statistical test, with a significance level of $5 \%(\alpha=0.05)$. Data processed using PAST software Version 2.17c (Hammer et al., 2001).

\section{RESULTS AND DISCUSSION}

\subsection{Microalgae Identification}

The results indicated the predominance of three species of microalgae in all light cycles; two diatoms; Nitzschia sp. and Gomphonema sp., and one Chlorophyta; Chlorella sp. According to Maity et al. (2014), species of the genera Nitzschia and Chlorella, like N. pusilla and $C$. vulgaris, are generally used to remove pollutants from wastewater, such as nitrogen, phosphorus and potassium. The genus Gomphonema comprises a group of highly diversified freshwater diatoms, characteristic of nutrient-rich environments, such as $G$. parvulum, classified as having an intermediate degree of tolerance to eutrophication (Lobo et al., 2016).

\subsection{Light cycles and effluent characterization}

\subsubsection{First light cycle $(12 \mathrm{~h} / 12 \mathrm{~h})$}

The measured values (mean \pm standard deviation) in samples of raw effluent (Raw), microalgae tank (MT), and constructed wetland (CW) in the first light cycle $(12 \mathrm{~h} / 12 \mathrm{~h})$ are found in Table 1. MT was responsible for $98.3 \%$ of turbidity removal, $93.6 \%$ of total organic carbon (TOC), $92.5 \%$ of apparent color, $82.0 \%$ of total carbon (TC), $67.5 \%$ of total nitrogen (TN), $66.9 \%$ of inorganic carbon (IC), $39.1 \%$ of conductivity and $25.7 \%$ of total dissolved solids (TDS). MT was also responsible for $100 \%$ of total suspended solids (TSS) removal. At the end of the treatment process of the first light cycle, $99.4 \%$ of turbidity removal was verified, $95.0 \%$ of apparent color, $89.1 \%$ of total carbon, $85.7 \%$ of total nitrogen, $69.5 \%$ of inorganic carbon, $50.6 \%$ of conductivity and $44.2 \%$ of TDS, as well as removal of $100.0 \%$ for total suspended solids, total organic carbon, total coliforms and E. coli.

Table 1. Mean concentration ( \pm standard deviation) of the analyzed parameters in the samples of raw effluent (Raw), microalgae tank (MT) and constructed wetland (CW) in the first light cycle (12h/12h).

\begin{tabular}{lccc}
\hline Parameters $^{*}$ & Raw & MT & CW \\
\hline pH & $6.6 \pm 0.2$ & $6.4 \pm 0.4$ & $6.6 \pm 0.3$ \\
Turbidity & $245.5 \pm 111.6$ & $4.2 \pm 4.1$ & $1.6 \pm 1.7$ \\
Conductivity & $847.1 \pm 369.0$ & $515.8 \pm 123.8$ & $418.0 \pm 65.0$ \\
Apparent color & $0.8 \pm 0.0$ & $0.1 \pm 0.0$ & $0.0 \pm 0.0$ \\
TDS & $378.1 \pm 225.1$ & $281.0 \pm 48.8$ & $211.1 \pm 33.0$ \\
TSS & $12.7 \pm 6.2$ & $0.0 \pm 0.0$ & $0.0 \pm 0.0$ \\
T. Coliforms & $1.9 \pm 1.9[\ln (\mathrm{x}+1)]$ & N.D. & $2.3 \pm 2.0$ \\
E. coli & $1.9 \pm 1.9[\ln (\mathrm{x}+1)]$ & N.D. & $0.0 \pm 0.0$ \\
TOC $(\mathrm{n}=4)$ & $78.5 \pm 31.1$ & $5.0 \pm 10.1$ & $0.0 \pm 0.0$ \\
IC $(\mathrm{n}=4)$ & $92.3 \pm 32.8$ & $30.5 \pm 24.4$ & $28.1 \pm 1.0$ \\
TC $(\mathrm{n}=4)$ & $171.0 \pm 63.0$ & $30.7 \pm 21.1$ & $18.6 \pm 1.1$ \\
TN $(\mathrm{n}=4)$ & $95.0 \pm 35.2$ & $30.9 \pm 5.0$ & $13.6 \pm 2.3$ \\
$\mathrm{P} \mathrm{Soluble}$ & $3.5 \pm 2.4$ & $2.6 \pm 1.8$ & $1.4 \pm 0.8$ \\
$\mathrm{NH}_{3}$ & $75.2 \pm 41.0$ & $9.8 \pm 8.3$ & $4.4 \pm 3.5$ \\
\hline
\end{tabular}

${ }^{*}$ Concentrations given in $\mathrm{mg} \mathrm{L}^{-1}$ with the exception of $\mathrm{pH}$ (dimensionless), conductivity $\left(\mu \mathrm{s} . \mathrm{cm}^{-1}\right)$, turbidity (NTU), color (dimensionless), total Coliforms/E. coli $\left(\mathrm{UFC} \mathrm{mL}^{-1}\right)$ and Temperature $\left({ }^{\circ} \mathrm{C}\right)$. N.D. $=$ Not determined. 
According to $\mathrm{Wu}$ et al. (2016), the removal of pathogenic microorganisms in wastewater is possible due to physical, chemical and biological mechanisms, alone or in combination. Physical mechanisms involve the filtration of microorganisms through the rhizosphere, fixation to the substrate and sedimentation, while chemical mechanisms include oxidation, UV radiation and exposure to biocides excreted by some plants. As biological mechanisms, we can mention the natural death of pathogens due to the absence of nutrients, predation and adsorption.

\subsubsection{Second light cycle (24h)}

For the second light cycle (24h) and the last light cycle (18h/06h) it was not possible to perform TOC, IC, TC and TN analysis, due to operational problems. The values measured (mean \pm standard deviation) in raw effluent samples (Raw), microalgae tank (MT) and constructed wetland (CW) in the second light cycle are found in Table 2. MT was responsible for $100 \%$ of TSS removal, $98.9 \%$ of turbidity, $53.6 \%$ of conductivity, $87.5 \%$ of apparent color and $53.1 \%$ of TDS. At the end of the second light cycle treatment process, $99.7 \%$ of turbidity removal was verified, $87.5 \%$ of apparent color, $77.2 \%$ of TDS and $75.0 \%$ of conductivity. There was also removal of $100 \%$ of TSS, total coliforms and E. coli.

Table 2. Mean concentration ( \pm standard deviation) of the analyzed parameters in the samples of raw effluent (Raw), microalgae tank (MT) and constructed wetland (CW) in the second light cycle (24h).

\begin{tabular}{lccc}
\hline Parameters $^{*}$ & Raw & MT & CW \\
\hline pH & $6.9 \pm 0.1$ & $7.1 \pm 0.1$ & $7.0 \pm 0.1$ \\
Turbidity & $244.0 \pm 324.4$ & $2.4 \pm 2.0$ & $0.8 \pm 0.8$ \\
Conductivity & $1179.1 \pm 349.0$ & $546.7 \pm 57.5$ & $293.1 \pm 58.2$ \\
Apparent color & $0.8 \pm 0.2$ & $0.1 \pm 0.1$ & $0.1 \pm 0.1$ \\
TDS & $591.1 \pm 174.6$ & $277.1 \pm 25.6$ & $134.5 \pm 67.1$ \\
TSS & $4.1 \pm 2.7$ & $0.0 \pm 0.1$ & $0.0 \pm 0.0$ \\
T. Coliforms & $1.9 \pm 1.9[\ln (\mathrm{x}+1)]$ & N.D. & $7.3 \pm 9.4$ \\
E. coli & $1.9 \pm 1.9[\ln (\mathrm{x}+1)]$ & N.D. & $0.0 \pm 0.0$ \\
P soluble & $3.7 \pm 0.3$ & $4.3 \pm 0.8$ & $1.2 \pm 1.0$ \\
NH 3 & $18.5 \pm 18.9$ & $2.3 \pm 1.3$ & $1.1 \pm 0.7$ \\
COD & $1088.6 \pm 29.2$ & $405.8 \pm 304.1$ & $395.1 \pm 316.1$ \\
BOD & $183.3 \pm 4.7$ & $102.1 \pm 113.1$ & $105.0 \pm 122.8$ \\
\hline
\end{tabular}

${ }^{*}$ Concentrations given in $\mathrm{mg} \mathrm{L}^{-1}$ with the exception of $\mathrm{pH}$ (dimensionless), conductivity $\left(\mu \mathrm{s} . \mathrm{cm}^{-1}\right)$, turbidity (NTU), color (dimensionless), total Coliforms $/ E$. coli $\left(\mathrm{UFC} \mathrm{mL}^{-1}\right)$ and Temperature $\left({ }^{\circ} \mathrm{C}\right)$. N.D. $=$ Not determined.

\subsubsection{Third light cycle $(18 \mathrm{~h} / 06 \mathrm{~h})$}

Table 3 shows the measured values (mean \pm standard deviation) in samples of raw effluent (Raw), microalgae tank (MT) and constructed wetland (CW), in the third light cycle. MT was responsible for $100 \%$ of the apparent color removal, $96.4 \%$ of the turbidity, $50.6 \%$ of the TDS and $49.6 \%$ of the conductivity. Also, there was $100 \%$ removal of the TSS. At the end of the treatment process in the third light cycle, there was $100 \%$ removal of apparent color, $99.6 \%$ of turbidity, $71.0 \%$ of TDS, $69.7 \%$ of conductivity and $100 \%$ of TSS, total coliforms and E. coli. All the results found at the end of the treatment process in the third light cycle were higher than those found by Celente et al. (2019). 
Table 3. Mean concentration ( \pm standard deviation) of the analyzed parameters in the samples of raw effluent (Raw), microalgae tank (MT) and constructed wetland (CW) in the third light cycle (18h/06h).

\begin{tabular}{cccc}
\hline Parameters $^{*}$ & Raw & MT & CW \\
\hline pH & $7.2 \pm 0.2$ & $7.4 \pm 0.1$ & $7.0 \pm 0.1$ \\
Turbidity & $111.0 \pm 65.9$ & $4.0 \pm 2.3$ & $0.4 \pm 0.4$ \\
Conductivity & $1316.8 \pm 705.0$ & $663.1 \pm 104.4$ & $398.4 \pm 72.0$ \\
Apparent color & $0,4 \pm 0,1$ & $0.0 \pm 0.0$ & $0.0 \pm 0.0$ \\
TDS & $674.0 \pm 361.5$ & $333.2 \pm 54.4$ & $195.2 \pm 38.7$ \\
TSS & $4,7 \pm 2,1$ & $0.0 \pm 0.0$ & $0.0 \pm 0.0$ \\
T. Coliforms & $1.9 \pm 1.9[\ln (\mathrm{x}+1)]$ & N.D. & $17.6 \pm 26.3$ \\
E. coli & $1.9 \pm 1.9[\ln (\mathrm{x}+1)]$ & N.D. & $0.0 \pm 0.0$ \\
P soluble & $2,8 \pm 0,6$ & $3.9 \pm 0.1$ & $2,1 \pm 0,1$ \\
NH $_{3}$ & $43.4 \pm 28.7$ & $2.8 \pm 3.3$ & $5.7 \pm 6.7$ \\
COD & $360.4 \pm 110.7$ & $195.8 \pm 100.3$ & $138.8 \pm 17.1$ \\
BOD & $240.8 \pm 111.4$ & $185.1 \pm 136.1$ & $142.8 \pm 115.1$ \\
\hline
\end{tabular}

"Concentrations given in $\mathrm{mg} \mathrm{L}^{-1}$ with the exception of $\mathrm{pH}$ (dimensionless), conductivity $\left(\mu \mathrm{s} . \mathrm{cm}^{-1}\right)$, turbidity (NTU), color (dimensionless), total Coliforms/E. coli (UFC $\mathrm{mL}^{-1}$ ) and Temperature $\left({ }^{\circ} \mathrm{C}\right)$. N.D. $=$ Not determined.

\subsection{Ecotoxicity}

Regarding acute toxicity, it was not possible to carry out tests on the raw and treated effluent in the first light cycle due to operational problems. In the second cycle of light (24h) the raw effluent was characterized as "highly toxic", as it presented a mean EC50 (48h) (acute concentration of the sample in $48 \mathrm{~h})$ of $44.6 \pm 38.1 \%$. In the third light cycle $(18 \mathrm{~h} / 06 \mathrm{~h})$, the raw effluent was characterized as "extremely toxic", as it had an average EC50 (48h) of $23.0 \pm$ $1.4 \%$.

Despite the high toxicity of the raw effluent in both light cycles, no toxicity was observed in the treated effluent. The toxicity of the raw effluent is closely related to nitrogen concentrations, since nitrogen is available in the form of nitrate, urea, ammonia and peptones (Minhas et al., 2016). For Alves et al. (2018), this nutrient found in different wastewater types, such as industrial and sanitary effluents, has negative impacts on the population dynamics of aquatic animals, if incorrectly disposed of in waterbodies. Some studies have demonstrated the negative effect of different concentrations of ammonia in aquatic animals, such as fish and crustaceans (Dos Santos Silva et al., 2018). The significant reduction in toxicity at the end of the treatment process is related to the mechanisms of nitrogen assimilation by the biofilm, and the nitrification process in nitrite and nitrate. As pointed out by Vymazal (2007), the reduction in toxicity cannot be associated with volatilization of ammonia $\left(\mathrm{NH}_{3}\right)$, since the $\mathrm{pH}$ remained below 9.5; the value in which approximately $50 \%$ of the ammoniacal nitrogen is present in the volatile $\mathrm{NH}_{4}{ }^{+}$form.

According to Cai et al. (2013), nitrogen is a necessary nutrient for the growth of many organisms, with organic nitrogen derived from inorganic sources, including nitrate $\left(\mathrm{NO}_{3}-\right)$, nitrite $\left(\mathrm{NO}_{2}-\right)$, nitric acid $\left(\mathrm{HNO}_{3}\right)$, ammonium $\left(\mathrm{NH}_{4}\right)$, ammonia $\left(\mathrm{NH}_{3}\right)$ and nitrogen gas $\left(\mathrm{N}_{2}\right)$, noting that microalgae convert inorganic to organic nitrogen through a process called assimilation. Also according to the authors, assimilation, carried out by all eukaryotic algae, requires inorganic nitrogen only in the form of nitrate, nitrite, and ammonium.

Franchino et al. (2016) verified the removal of ecotoxicity with the microalgae Chlorella vulgaris grown in the effluent of anaerobic digestion of swine and corn manure, observing a high removal efficiency (>90\%) for total ammonia, nitrogen and phosphate. Almeida et al. (2017), in their study on the removal of nitrate in vertical flow constructed wetlands with 
Vetiveria zizanioides, found low concentrations of $\mathrm{NH}_{4}$, suggesting that the reduction of nitrate in ammonia was not the main factor for the removal of nitrate in the wetland system. The authors relate the effluent detoxification to the large extension of macrophyte roots in the wetland tank.

\subsection{Nutrient removal}

For soluble phosphorus $(\mathrm{n}=4)$, ammoniacal nitrogen $\left(\mathrm{NH}_{3}\right)(\mathrm{n}=4), \mathrm{COD}(\mathrm{n}=3)$ and BOD $(n=3)$, no significant differences $(p>0.05)$ were found between the MT values, comparing the three photoperiod cycles $(12 \mathrm{~h} / 12 \mathrm{~h}, 24 \mathrm{~h}$ and $18 \mathrm{~h} / 06 \mathrm{~h})$, as noted in Tables 1,2 and 3 . It is important to highlight, however, that the composite system configuration demonstrated high nutrient removal efficiency. Figure 2 shows the results related to the removal of soluble phosphorus and ammoniacal nitrogen in the three light cycles.
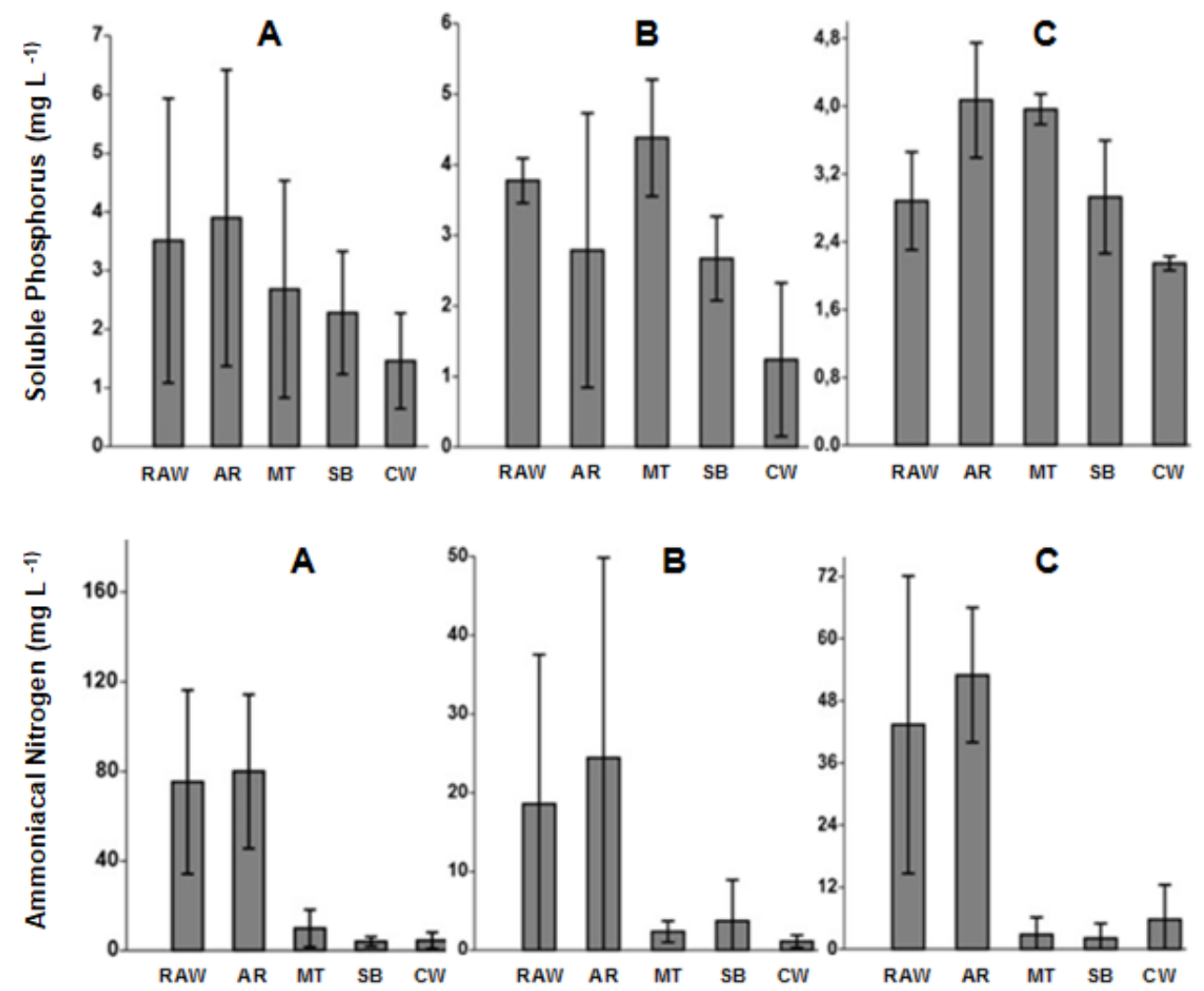

Figure 2. Mean concentration ( \pm standard deviation) of soluble phosphorus $\left(\mathrm{mg} \mathrm{L}^{-1}\right)$ and ammoniacal nitrogen $\left(\mathrm{mg} \mathrm{L}^{-1}\right)$ over the three light cycles. A: First light cycle (12h/12h). B: Second light cycle (24h). C: Third light cycle (18h/06h).

Regarding the removal of soluble phosphorus in the first light cycle, Table 1 and Figure 2 shows that MT was responsible for $25.7 \%$ of removal. At the end of the treatment, $60.0 \%$ was removed. In the second light cycle, there was an increase of $16.0 \%$ in the concentration of soluble phosphorus in MT compared to the raw effluent. At the end of the treatment process, $67.6 \%$ of the soluble phosphorus was removed from the raw effluent. In the third light cycle, there was an increase of $39.3 \%$ in the concentration of soluble phosphorus in MT compared to the raw effluent. The reduction of this parameter was verified at the end of the treatment process (CW), where $25.0 \%$ of phosphorus was removed. According to Chung et al. (2009), the increase in the concentration of soluble phosphorus in MT may be caused by the resuspension of sediments that are stored over time in the anaerobic reactor, and when released, they contribute to altering the dynamics of nutrients. Another factor that may have contributed to the addition 
of soluble P after MT may be related to the life cycle of microalgae, since during the decay phase, that is, cell death, the cellular content may add soluble $\mathrm{P}$ to the wastewater, thus increasing the load for the Sand Biofilter System + CW (Silveira et al., 2017).

Regarding phosphorus removal, the most efficient light cycle at the end of the treatment process was the $24 \mathrm{~h}$ cycle, with $67.6 \%$ efficiency, followed by $12 \mathrm{~h} / 12 \mathrm{~h}$ cycle with $60.0 \%$, and $18 \mathrm{~h} / 06 \mathrm{~h}$ cycle with $25.0 \%$. Likewise, Sukačová et al. (2015) observed that the 24-hour photoperiod had the highest phosphorus removal efficiency of $97 \%$, using microalgae for tertiary water treatment. In the $12 \mathrm{~h} / 12 \mathrm{~h}$ photoperiod, phosphorus removal ranged from $36 \%$ to $41 \%$. According to Martinez et al. (1999), the removal of phosphorus by microalgae is possible since this nutrient is essential for its energy metabolism, being found in nucleic acids, lipids and proteins. Furthermore, inorganic phosphates play a significant role in the growth and metabolism of young cells, preferably in the forms of $\mathrm{H}_{2} \mathrm{PO}_{4}{ }^{-}$and $\mathrm{HPO}^{2}{ }_{4}^{-}$, where it is incorporated into organic compounds by means of phosphorylation.

Table 1 and Figure 2 show the results of the ammoniacal nitrogen removal in the first light cycle, indicating that the microalgae tank was responsible for $86.9 \%$ of removal. At the end of the treatment, $94.1 \%$ was removed. In the second light cycle, MT was responsible for $87.6 \%$ of removal. At the end of the treatment process, $94.0 \%$ of the ammoniacal nitrogen was removed from the raw effluent. In the third cycle, MT was responsible for $93.5 \%$ of removal, while at the end of the treatment process, $86.9 \%$ was removed.

Tables 1, 2 and 3 show that the raw effluent presents $\mathrm{NH}_{3}$ concentrations higher than typical values for raw domestic effluent in developing countries, according to Von Sperling (2006). The author points out that the normal concentrations of these effluents vary between 20 - $35 \mathrm{mg} \mathrm{L}^{-1}$, which differs from our results, which vary between 18.6 and $75.2 \mathrm{mg} \mathrm{L}^{-1}$. The reason for the high $\mathrm{NH}_{3}$ load can be attributed to the increased contribution of urea to the effluent, since urea is rapidly hydrolyzed to ammonia. It is important to note that even with a high eutrophic load, the ammonia nitrogen concentration was considerably reduced from the MT in the three light cycles. According to Norström et al. (2003), ammonia is the most assimilated form of nitrogen by algae; therefore, biofilm assimilation is the main mechanism for the high efficiency of ammonia nitrogen removal.

Considering the high removal of $94.1 \%$ of $\mathrm{NH}_{3}$ over the $12 \mathrm{~h} / 12 \mathrm{~h}$ cycle, the combined use of microalgae + constructed wetland becomes more efficient in removing this parameter than studies using only wetlands for sewage treatment (e.g., Dos Santos et al., 2018).

As for Chemical Oxygen Demand (COD) and Biochemical Oxygen Demand (BOD), only analyses of the last two light cycles ( $24 \mathrm{~h}$ and $18 \mathrm{~h} / 06 \mathrm{~h}$ ) were performed, due to technical operational problems. Table 2 shows that in the second cycle ( $24 \mathrm{~h}$ light) the removal of COD in MT was $62.7 \%$ and $63.7 \%$ at the end of the treatment process $(\mathrm{CW})$. In the $18 \mathrm{~h} / 06 \mathrm{~h}$ cycle, $46.7 \%$ of COD was removed in MT and 61.5\% at the end of treatment (Table 3). Based on these results, it can be verified that the microalgae tank showed low removal rates in the two light cycles. However, in the second cycle, the microalgae removed a higher percentage of COD compared to the third cycle. The low rate of organic matter removal can be attributed to the following factors: turbidity, low concentrations of organic substrate in the effluent - especially in the third cycle - and temperature. According to Xia and Murphy (2016), the high turbidity of the effluent caused by suspended materials is an important factor influencing the efficiency of organic matter removal, since photosynthesis performed by microalgae is dependent on the availability of photosynthetically active radiation (PAR) $(400-700 \mathrm{~nm})$ and high turbidity leads to a reduction in PAR and, consequently, reduces microalgal growth.

Table 2 shows that in the second cycle (24h light) the removal of BOD in MT was $44.3 \%$, while at the end of the treatment process the removal was $42.7 \%$. In the light cycle of $18 \mathrm{~h} / 06 \mathrm{~h}$, the removal of BOD in MT was $23.1 \%$, while at the end of the treatment process, removal was $40.7 \%$ (Table 3). The likely cause of this low BOD removal is related to outdoor temperatures, 
as the study was conducted during the winter and spring seasons. According to GonzálezFernández et al. (2016), temperature is an important physical factor in the removal of nutrients, since it directly affects the metabolic rate of microalgae. The authors exposed the species Chlorella vulgaris, Scenedesmus obliquus and Chlamydomonas reindhardtii in three scenarios with different environmental conditions, and observed that microalgae grew faster and reached maximum growth after 6 days of cultivation at $23^{\circ} \mathrm{C}$ and $14 \mathrm{~h}$ of light.

The removal efficiency in both cycles $(42.7 \%$ for $24 \mathrm{~h}$ and $40.7 \%$ for $18 \mathrm{~h} / 06 \mathrm{~h}$ ) was lower than the values found by Ramos et al. (2017) in constructed wetlands, without microalgae, for wastewater treatment using the vetiver grass Chrysopogon zizanioides to remove BOD, nitrogen and phosphorus. They found $81.0 \%$ effectiveness in removing BOD, almost double that of the present study. This condition can be explained by the high variability of the data, demonstrated by the high standard deviation values of the mean BOD concentrations, which varied greatly in both light cycles, especially in the 24-hour cycle. For example, in MT the mean concentration ( \pm standard deviation) was $102.1 \pm 113.1$ (Coefficient of Variation, CV $=$ $110.8 \%)$ as for $\mathrm{CW}$ of $105.0 \pm 122.8(\mathrm{CV}=117.0 \%)$. This high variability $(>100 \% \mathrm{CV})$ is statistically related to the low average BOD removal efficiency.

\section{CONCLUSIONS}

There were no significant differences $(\mathrm{p}>0.05)$ between the values of soluble phosphorus, ammoniacal nitrogen, COD and BOD for MT comparing the three photoperiod cycles $(12 \mathrm{~h} / 12 \mathrm{~h}$, $24 \mathrm{~h}$ and $18 \mathrm{~h} / 06 \mathrm{~h}$ ). However, the system setup removed $100 \%$ of total coliforms, E. coli and TSS in the three light cycles. Regarding the removal of nutrients and organic matter, the light cycle with the best performance was 24-hour, considering a removal of $67.6 \%$ for soluble phosphorus, $94.0 \%$ for ammoniacal nitrogen, $63.7 \%$ for COD and $42.7 \%$ for BOD, at the end of the treatment process. These results demonstrate that the use of microalgae in combination with constructed wetland has greater efficiency in removing nutrients, especially phosphorus and nitrogen, in addition to reducing physical-chemical parameters and eliminating effluent toxicity.

\section{FUTURE PROSPECTIVE RESEARCH AND FIELD APPLICATION}

This research showed high efficiency in the removal of nutrients, being an excellent alternative for application in developing countries, due to its low cost compared to conventional wastewater treatment technologies. Future research should focus on monitoring the removal of nutrients and organic matter for a longer period that contemplates the four seasons of the year, relating the interference of temperature on the growth of microalgae and, consequently, in the treatment of effluents. We emphasize the need for additional chronic ecotoxicity tests in future studies to confirm the absence of toxicity, as acute tests may fail to detect the toxic effects of some compounds.

\section{ACKNOWLEDGEMENTS}

We would like to thank the Coordenação de Aperfeiçoamento de Pessoal de Nível Superior - Brasil (CAPES) for partially funding of this research.

\section{REFERENCES}

ABNT. NBR 12713. Aquatic ecotoxicology - Acute Toxicity - Test with Daphnia spp (Cladocera, Crustacea). Rio de Janeiro, 2016. 
ALMEIDA, A.; CARVALHO, F.; IMAGINÁRIO, M. J.; CASTANHEIRA, I.; PRAZERES, A. R.; RIBEIRO, C. Nitrate removal in vertical flow constructed Wetland planted with Vetiveria zizanioides: Effect of hydraulic load. Ecological Engineering, v. 99, p. 535542, 2017. https://dx.doi.org/10.1016/j.ecoleng.2016.11.069

ALVES, C. F.; BOCOLI, C. B.; OlIVEIRA, E. P.; PIZZO, M. M.; RODRIGUEZ, R. P. Remoção biológica de nitrogênio em águas residuárias: uma revisão dos processos convencionais aos processos modernos. Revista Ibero Americana de Ciências Ambientais, v. 9, n. 3, p. 174-187, 2018. http://doi.org/10.6008/CBPC21796858.2018.003.0015

AOAC. Official methods of analysis of the Association of Official Analytical Chemists. Rockville, 2000.

APHA; AWWA; WEF. Standard Methods for the examination of water and wastewater. 22nd ed. Washington, 2012. 1496 p.

ARIHILAM, N.; ARIHILAM, E. Impact and control of anthropogenic pollution on the ecosystem-A review. Journal of Bioscience and Biotechnology Discovery, v. 4, n. 3, p. 54-59, 2019. http://dx.doi.org/10.31248/JBBD2019.098

BFG - THE BRAZIL FLORA GROUP. Growing knowledge: an overview of Seed Plant diversity in Brazil. Rodriguésia, v. 66, n. 4, p. 1085-1113, 2015. http://dx.doi.org/10.1590/2175-7860201566411

CAI, T.; PARK, S. Y.; LI, Y. Nutrient recovery from wastewater streams by microalgae: Status and prospects. Renewable and Sustainable Energy Reviews, v. 19, p. 360-369, 2013. http://dx.doi.org/10.1016/j.rser.2012.11.030

CELENTE; G. S.; COLARES, G. S.; MACHADO, E. L.; LOBO, E. A. Algae turf scrubber and vertical constructed wetlands combined system for decentralized secondary wastewater treatment. Environmental Science and Pollution Research, v. 26, n. 10, p. 9931-9937, 2019. https://doi.org/10.1007/s11356-019-04425-6

CELENTE, G. S.; COLARES., G. S.; ARAÚJO, P. S.; MACHADO, E. L.; LOBO, E. A. Acute ecotoxicity and genotoxicity assessment of two wastewater treatment units. Environmental Science and Pollution Research, v. 27, p. 10520-10527, 2020. https://doi.org/10.1007/s11356-019-07308-y

CHUNG, E. G.; BOMBARDELLI, F. A.; SCHLADOW, S. G. Modeling linkages between sediment resuspension and water quality in a shallow, eutrophic, wind-exposed lake. $\begin{array}{llllll}\text { Ecological Modelling, } 2009 . & \text { v. 220, p. 1251-1265, }\end{array}$ https://doi.org/10.1016/j.ecolmodel.2009.01.038

DOS SANTOS, M. O.; PELISSARI, C.; ROUSSO, B. Z.; DE FREITAS, M. N.; SEZERINO, P. H. Avaliação dos dois primeiros anos de operação de um wetland construído vertical de fundo saturado aplicado no tratamento de esgoto sanitário. Tecno-Lógica, v. 22, n. 1, p. 25-29, 2018. http://dx.doi.org/10.17058/tecnolog.v22i1.10500

DOS SANTOS SILVA, M.; DA COSTA, F.; LEME, F. P.; TAKATA, R.; COSTA, D. C.; MATTIOLI, C. C. et al. Biological responses of Neotropical freshwater fish Lophiosilurus alexandri exposed to ammonia and nitrite. Science of the Total $\begin{array}{lllll}\text { Environment, } & \text { v. } & 616, & \text { p. } & 1566-1575,\end{array}$ https://doi.org/10.1016/j.scitotenv.2017.10.157 
FONSECA, J. C. J.; SILVA, M. R. A.; BAUTITZ, I. R.; NOGUEIRA, R. F. P.; MARCHI, M. R. R. Assessment of the analytical reliability of the total organic carbon (TOC) determinations. Eclética Química, v. 31, n.3, p. 47-52, 2006. http://dx.doi.org/10.1590/S0100-46702006000300006

FRANCHINO, M.; TIGINI, V.; VARESE, G. C.; MUSSAT SARTOR, R.; BONA, F. Microalgae treatment removes nutrients and reduces ecotoxicity of diluted piggery digestate. Science of The Total Environment, v. 569 p. 40-45, 2016. http://dx.doi.org/10.1016/j.scitotenv.2016.06.100

GONZÁLEZ-FERNÁNDEZ, C.; MAHDY, A.; BALLESTEROS, I.; BALLESTEROS, M. Impact of temperature and photoperiod on anaerobic biodegradability of microalgae grown in urban wastewater. International Biodeterioration \& Biodegradation, v. 106, p. 16-23, 2016. http://dx.doi.org/10.1016/j.ibiod.2015.09.016

GRUIZ, K.; MOLNÁR, M. Aquatic toxicology. In: GRUIZ, K.; MEGGYES, T.; FENYVESI, E. (eds.). Environmental Toxicology. Boca Raton: CRC Press, 2015. p.171-228.

HAMMER, Ø.; HARPER, D. A. T.; RYAN, P. D. PAST: Paleontological Statistics Software Package for Education and Data Analysis. Palaeontologia Electronica, v. 41, p. 1-9, 2001.

HAMILTON, M. A.; RUSSO, R.; THURSTON, R. V. Trimmed Spearman-Karber method for estimating median lethal concentrations in toxicity bioassays. Environmental Science \& Technology, v. 11, n. 7, p. 714-719, 1977. http://dx.doi.org/doi:10.1021/es60130a004

LIANG, Y.; ZHU, H.; BAÑUELOS, G.; YAN, B.; ZHOU, Q.; YU, X.; CHENG, X. Constructed Wetland for saline wastewater treatment: A review. Ecological Engineering, v. 98, p. 275-285, 2017. https://doi.org/10.1016/j.ecoleng.2016.11.005

LOBO, E. A.; RATHKE, F. S.; BRENTANO, D. M. Applied ecotoxicology: the case of tobacco growers in the Pardinho River basin, RS, Brazil. In: ETGES, V. E.; FERREIRA, M. A. F. Tobacco production: impact on the ecosystem and human health in the region of Santa Cruz do Sul, RS. Santa Cruz do Sul: Edunisc, 2006. p 41-68.

LOBO, E.; HEINRICH, C.; SCHUCH, M.; WETZEL, C.; ECTOR, L. Diatoms as bioindicators in rivers. In: NECCHI JR., O. (eds.). River Algae, Springer, 2016. p. 245-271. http://dx.doi.org/10.1007/978-3-319-31984-1_11

MAITY, J. P; BUNDSCHUH, J.; CHEN, C. Y.; BHATTACHARYA, P. Microalgae for third generation biofuel production, mitigation of greenhouse gas emissions and wastewater treatment: Present and future perspectives - A mini review. Energy, v. 78, p. 104-113, 2014. http://doi.org/10.1016/j.energy.2014.04.003

MARTINEZ, M.E.; JIMENEZ, J.M.; EL YOUSFI, F. Influence of phosphorus concentration and temperature on growth and phosphorus uptake by the microalga Scenedesmus obliquus. Bioresource Technology, Amsterdã, v. 67, p. 233-240, 1999. https://dx.doi.org/10.1016/s0960-8524(98)00120-5

METCALF, L.; EDDY, H. P. Tratamento de Efluentes e Recuperação de Recursos. Porto Alegre: McGraw Hill Education, 2016. 2008 p. 
MINHAS, A. K; HODGSON, P.; BARROW, C. J.; ADHOLEYA, A. A review on the assessment of stress conditions for simultaneous production of microalgal lipids and

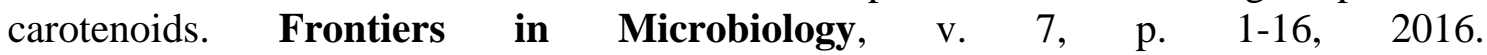
https://dx.doi.org/10.3389/fmicb.2016.00546

NORSTRÖM, A.; LARSDOTTER, K.; GUMAELIUS, L.; LA COUR JANSEN, J.; DALHAMMAR, G. A. A small scale hydroponics wastewater treatment system under Swedish conditions. Water Science \& Technology, v. 48, p. 161-167, 2003. https://dx.doi.org/10.2166/wst.2004.0830

PACHECO, M.; HOELTZ, M.; MORAES, M.; SCHNEIDER, R. Microalgae: cultivation techniques and wastewater phycoremediation. Journal of Environmental Science and Health, v. 50, p. 585-601, 2015. https://dx.doi.org/10.1080/10934529.2015.994951

RAMOS, N.; BORGES, A.; GONÇALVES, G.; MATOS, A. Tratamento de águas residuárias de suinocultura em sistemas alagados construídos, com Chrysopogon zizanioides e Polygonum punctatum cultivadas em leito de argila expandida. Engenharia Sanitária e Ambiental, v. 22, n. 1, p. 123-132, 2017. https://doi.org/10.1590/s1413-4152201687067

REHMAN, F.; PERVEZ, A.; MAHMOOD, Q.; NAWAB, B. Wastewater remediation by optimum dissolve oxygen enhanced by macrophytes in constructed Wetlands. Ecological Engineering, v. 102, p. 112-126, 2017. https://doi.org/10.1016/j.ecoleng.2017.01.030

SALAMA, E.; KURADE, M.; ABOU-SHANAB, R.; EL-DALATONY, M.; YANG, I.; MIN, B.; JEON, B. Recent progress in microalgal biomass production coupled with wastewater treatment for biofuel generation. Renewable and Sust. Energy Reviews, v. 79, p. 11891211, 2017. https://dx.doi.org/10.1016/j.rser.2017.05.091

SILVEIRA, E.; MOURA, D.; RIEGER, A.; MACHADO, Ê.; LUTTERBECK, C. A. Performance of an integrated system combining microalgae and vertical flow constructed wetlands for urban wastewater treatment. Environmental Science and Pollution Research, v. 24, n. 25, p. 20469-20478, 2017. https://dx.doi.org/10.1007/s11356-0179656-3

SUKAČOVÁ, K.; TRTÍLEK, M.; RATAJ, T. Phosphorus removal using a microalgal biofilm in a new biofilm photobioreactor for tertiary wastewater treatment. Water research, v. 71, p. 55-63, 2015. https://dx.doi.org/10.1016/j.watres.2014.12.049

TUNDISI, J. G.; MATSUMURA-TUNDISI, T. Limnologia. São Paulo: Oficina de Textos, 2008. 631p.

VACCA-JIMENO, V. A.; ANGULO-MERCADO, E. R.; PUENTES-BALLESTEROS, D. M.; TORRES-YÉPEZ, J. G.; PLAZA-VEGA, M. E. Uso de la microalga Chlorella sp. viva en suspensión en la decoloración del agua residual de una empresa textil. Prospectiva, v. 15, n. 1, p. 93-99, 2017. https://doi.org/10.15665/rp.v15i1.829

VON SPERLING, M. Wastewater Characteristics, Treatment and Disposal. London: IWA Publishing, 2006. 306 p.

VYMAZAL, J. Removal of nutrients in various types of constructed wetlands. Science of the $\begin{array}{llllll}\text { Total Environment, } & \text { v. } & 380, & \text { p. }\end{array}$ https://dx.doi.org/10.1016/j.scitotenv.2006.09.014 
XIA, A.; MURPHY, J. D. Microalgal cultivation in treating liquid digestate from biogas systems. Trends in Biotechnology, v. 34, n. 4, p. 264-275, 2016. https://dx.doi.org/10.1016/j.tibtech.2015.12.010

WANG, Q.; HU, Y.; XIE, H.; YANG, Z. Constructed Wetlands: A Review on the Role of Radial Oxygen Loss in the Rhizosphere by Macrophytes. Water, v. 10, n. 6, p. 1-11, 2018. https://dx.doi.org/10.3390/w10060678

WU, S.; CARVALHO, P. N.; MÜLlER, J. A.; MANOJ, V. R.; DONG, R. Sanitation in constructed wetlands: a review on removal on the removal of human pathogen and faecal indicators. Science of The Total Environment, v. 541, p. 8-22. 2016. https://doi.org/10.1016/j.scitotenv.2015.09.047

YI, H.; LI, M.; HUO, X.; ZENG, G.; LAI, C.; HUANG, D.; ZHANG, M. Recent development of advanced biotechnology for wastewater treatment. Critical reviews in biotechnology, Oxfordshire, v. 40. n.1, p. 99-118, 2020. https://doi.org/10.1080/07388551.2019.1682964 